\title{
O discurso da democracia: imprensa e hegemonia da ditadura empresarial-militar brasileira (1964-1968)'
}

\begin{abstract}
Resumo
Este artigo discute o uso da retórica da democracia no processo de construção da hegemonia da ditadura empresarial-militar implantada no Brasil em 1964. Precisamente, procura analisar o discurso da grande imprensa brasileira durante o período compreendido entre o golpe de 31 de março de 1964 até o momento imediatamente posterior à edição do Ato Institucional n. ${ }^{\circ}$, em 13 de dezembro de 1968 , e a construção da ideia da defesa da democracia como instrumento de criação de consenso, visando à legitimação da dominação de classe.
\end{abstract}

Palavras-chave: Ditadura Empresarial-Militar e Imprensa. Hegemonia. Democracia.

\section{Cláudio Beserra de Vasconcelos}

Doutor em História Social pela Universidade Federal do Rio de Janeiro (UFRJ). Professor na Secretaria de Educação do Estado do Rio de Janeiro (SEEDUC).

Rio de Janeiro, RJ - BRASIL cb.vasconcelos@yahoo.com.br orcid.org/0000-0002-3907-7158

\section{Para citar este artigo:}

VASCONCELOS, Cláudio Beserra de. O discurso da democracia: imprensa e hegemonia da ditadura empresarial-militar brasileira (1964-1968). Tempo e Argumento, Florianópolis, v. 11, n. 28, p. 365 - 401, set./dez. 2019.

\section{DOI: $10.5965 / 2175180311282019365$}

http://dx.doi.org/10.5965/2175180311282019365

\footnotetext{
${ }^{1}$ Pesquisa realizada com apoio da Coordenação de Aperfeiçoamento de Pessoal de Nível Superior (Capes) e do Conselho Nacional de Desenvolvimento Científico e Tecnológico (CNPq).
} 


\title{
The democracy's speech: press and hegemony of the brazilian entrepreneurial-military dictatorship (1964-1968)
}

\begin{abstract}
This article discusses the use of the democracy rhetoric in the construction of hegemony process of the entrepreneurial-military dictatorship implanted in Brazil in 1964. Mainly, it tries to analyze the great brazilian press' speech between the coup of March 31th 1964 and the immediately posterior moment to the edition of the Institutional Act n. ${ }^{\circ}$, in December 13th 1968, and the construction of the idea of democracy defense as the instrument of consensus building, aimed at legitimation of the class domination.
\end{abstract}

Keywords: Entrepreneurial-Military Dictatorship and Press. Hegemony. Democracy.

\section{Introdução}

Não houve governo na história que tenha baseado o seu domínio exclusivamente no uso e/ou na ameaça do uso de instrumentos de coerção. Como percebe Antonio Gramsci (2007, p. 95):

O exercício "normal" da hegemonia, no terreno clássico do regime parlamentar, caracteriza-se pela combinação da força e do consenso, que se equilibram de modo variado, sem que a força suplante em muito o consenso, mas, ao contrário, tentando fazer com que a força pareça apoiada no consenso da maioria, expresso pelos chamados órgãos da opinião pública - jornais e associações -, os quais, por isso, em certas situações, são artificialmente multiplicados. (...).

Esse pequeno trecho da obra do filósofo marxista aponta para dois elementos básicos da análise ora desenvolvida. Primeiro, para estabelecer a hegemonia, é preciso, além do uso da força, também construir um consenso com relação a certas ideias e 
valores junto a determinadas parcelas do corpo social que possam lhe servir de base. Isso pode possibilitar a redução da necessidade do recurso à coerção para a manutenção do poder ou, em caso de emprego, assentimento quanto a tal. Esse consenso finda por reproduzir a ordem social, legitimando a dominação de uma classe sobre outras. Esse fato é significativamente mais relevante desde fins do século XIX, e particularmente mais notável a partir de meados do século XX, quando todo governo, fosse ele democrático ou autoritário, para garantir o seu domínio, passou a buscar a legitimação das decisões políticas, em particular, através de um vínculo destas à defesa da democracia.

Segundo, no excerto, Gramsci (2007) destaca o papel que os órgãos da opinião pública exercem na construção desse consenso. Em outro momento de suas análises, o filósofo italiano explica que a mencionada opinião pública funciona como ponto de contato entre a sociedade civil e a sociedade política, entre consenso e força (GRAMSCI, 2007, p. 265). Para entendimento dessa observação, é preciso ter em conta que Gramsci entende sociedade política como o aparato governamental e coercitivo, e a sociedade civil como compreendendo as organizações - entre elas, os meios de comunicação responsáveis pela elaboração e/ou difusão de ideologias, e que o Estado é formado pelo somatório desses dois elementos (GRAMSCI, 2007). Logo, quando menciona que "o Estado, quando quer iniciar uma ação pouco popular, cria preventivamente a opinião pública adequada, ou seja, organiza e centraliza certos elementos da sociedade civil” (GRAMSCI, 2007, p. 265), Gramsci está trabalhando com uma concepção "integral” ou "ampliada" do Estado². Como resultado, em um contexto de Estado ampliado, tornam-se mais amplas as formas de se educar para o consenso, e a sociedade civil, da qual fazem parte os jornais, é o local específico para execução dessa tarefa.

A ditadura instaurada no Brasil em 1964 não foge a esse padrão. Ao menos até dezembro de 1968, em busca de sustentação às ações do governo, os novos donos do poder procuraram estabelecer um consenso junto a determinados grupos e, ao invés de buscarem a imposição exclusivamente pela força, optaram por reivindicar um perfil que

\footnotetext{
2 Gramsci usa o termo "Estado integral”. Contudo, vários autores preferem "Estado ampliado", compartilhando o entendimento de Christine Buci-Glucksmann, que considera que tal definição, deduzida dos textos do filósofo, indica melhor a relação de unidade-distinção entre Estado e sociedade civil (Cf. LIGUORI, Guido. Roteiros para Gramsci. Rio de Janeiro: Editora UFRJ, 2007).
} 
não só garantisse o consentimento, como também fosse capaz de reproduzir a dominação. Por haver se instaurado por via não institucionalizada o novo regime não contava com uma base que lhe conferisse essa legitimação. Precisou forjá-la. O foco se deu sobre as elites e as classes médias e alta. Jornais da grande imprensa nacional foram parceiros por excelência do governo nesse processo. O argumento: a defesa da democracia.

A intenção deste texto é, pois, discutir o uso da retórica da democracia, presente no discurso da grande imprensa brasileira, no processo de construção da hegemonia do regime implantado em 1964. Como corte cronológico, utiliza-se o período compreendido entre o golpe de 31 de março de 1964 e o momento imediatamente posterior à edição do Ato Institucional n. ${ }^{\circ}$, em 13 de dezembro de 1968, momento de maior fechamento do regime, quando as bases de legitimação sofrem alterações.

\section{O discurso como meio de dominação de classe}

Partindo do entendimento de que a hegemonia de determinando grupo depende, em parte, da construção de um consenso acerca de certas ideias, torna-se necessária a formação de uma base social que Ihe sirva de suporte. Quais setores devem constituir esse alicerce e como convencê-los a tal apresentam-se como questões centrais desse processo.

A escolha da base social não deve se pautar em uma questão meramente numérica. Os atores que podem ser convocados em defesa do grupo hegemônico não precisam constituir necessariamente a maioria, mas parecer refletir o consenso dessa maioria. Além disso, essa base social, como afirma Pierre Bourdieu (2000), não precisa ser uma classe no sentido de grupo mobilizado, mas sim uma classe provável, composta por um conjunto de agentes que ocupem posições semelhantes e hierarquicamente superiores no espaço social. Esses agentes, "colocados em condições semelhantes e sujeitos a condicionamentos semelhantes, têm, com toda a probabilidade, atitudes e interesses semelhantes, logo, práticas e tomadas de posições também semelhantes" (BOURDIEU, 2000, p. 136), o que Ihes possibilitaria, segundo o autor reconhecer o capital simbólico e reforçar o poder simbólico da classe dirigente. Ao mesmo tempo, serviriam de 
reserva de poder que possibilitaria o estabelecimento do consenso desejado pelos dirigentes (BOURDIEU, 2000).

No caso brasileiro pós-golpe de 1964, os grupos nos quais o regime buscou esse suporte foram as camadas médias e alta da sociedade. No que se refere em específico às classes médias, conforme Marilena Chauí (1978), tanto do ponto de vista histórico efetivo, quanto do ponto de vista da posição estrutural, elas não se apresentam como portadoras de um projeto político autônomo, de sorte que, bem ou mal, estão atreladas às classes dominantes ou a reboque delas. Por conseguinte, nos termos de Bourdieu, as classes médias terão interesses, tomadas de posição e práticas semelhantes às classes dominantes, findando por reforçar o "poder simbólico" dos dirigentes. Uma das diferentes formas de fazer isso é através da chancela ao discurso dos detentores do poder.

Mais do que apenas um instrumento de comunicação, o discurso é um objeto histórico-social, visto estar relacionado ao contexto no qual foi gerado. Disso resulta que, como afirmam Ciro Flamarion Cardoso e Ronaldo Vainfas (1997, p. 378. Grifos dos autores), em análise sobre a obra do semiótico Eliseo Verón, “as 'condições de produção' de um discurso têm a ver com o 'ideológico', com os valores sociais da sociedade que o produz”, e “as 'condições de seu reconhecimento' dependem do poder, isto é, das instâncias capazes de legitimar ou não a sua aceitação na sociedade”.

Essas características levam à percepção, nos termos de Marx e Engels, de que, embora não sejam os únicos, "os pensamentos da classe dominante são também, em todas as épocas, os pensamentos dominantes" (MARX; ENGELS, 1998, p. 48). Em outros termos, o discurso hegemônico exprime ideias, portanto, ideologias, determinadas pelo grupo cuja posição social for hierarquicamente superior. O resultado é o reforço da própria posição hegemônica desses setores. No que concerne às classes médias, por estarem atreladas às classes dominantes, as ideias que elas disseminam, em última instância, são oriundas dos detentores do poder. Ao propagá-las, contribuem no estabelecimento do consenso que legitima a dominação de classes. Essa natureza faz com que tanto o discurso originário nessas camadas quanto o que é voltado para elas contribuam, ao fim, para a reprodução da ordem social. 


\section{Sobre como fazer o discurso chegar aos grupos-alvos}

Era preciso fazer com que o discurso dominante chegasse aos grupos que pudessem servir de suporte de poder. Mas, somente com a criação da Assessoria Especial de Relações Públicas da Presidência da República (AERP), em 15 de janeiro de 1968, o regime passou a contar com uma instituição que fazia parte da máquina estatal, em sentido estrito, e servia como divulgadora de suas ações (FICO, 1997). Na sua primeira fase, havia a consciência de que a ditadura carecia de um órgão que colaborasse na produção do seu “capital simbólico", necessário à construção do consenso em torno do projeto de dominação que se estabelecia. Como em uma perspectiva de Estado ampliado cabe à sociedade civil executar esse papel de educador para o consenso, e sendo a grande imprensa jornalística parte dessa fração do Estado, ela se mostrou apta a desempenhar o importante papel na produção desse “capital”. É preciso entender, porém, como ela, mídia já firmemente estabelecida, pôde atuar na construção de um consenso em prol da hegemonia dos grupos que conquistaram o poder em 1964.

De acordo com Luís Felipe Miguel (1999), em nosso mundo, temos contato apenas com um pequeno número de informações das quais precisamos e o jornalismo vem suprir essa nossa necessidade. Nesse processo, ele impõe à sociedade seus critérios de seleção e hierarquização de informações, institucionaliza os dizeres que devem ser ditos/repetidos e procura "fazer crer", através de narrativas que visam dar sentido à história. Como no discurso jornalístico o locutor se impõe como "perito", ele não apresenta dúvidas e contradições, o que lhe possibilita pedir ao povo a renovação da confiança em si e no referente. Na medida em que se confia no veículo, no locutor, seus critérios passam a ser considerados "naturais" e indiscutíveis. Logo, reorganizando a história, o discurso jornalístico contribui para a representação e "re-produção" de uma ilusão de consensos ou dissensos, inclusive no que se refere aos detentores do poder (MARIANI, 1998). Finda, pois, por se tornar um caminho de difusão, disseminação e institucionalização das práticas discursivas de exercício do poder.

Por conter tais características, o discurso jornalístico se mostrava apto a exercer um papel fundamental no processo de construção das imagens do regime instaurado em 1964. E o cumpriu com maestria. A imprensa assumiu um papel estratégico dentro do 
projeto do novo sistema de dominação elaborado pelos grupos no poder. Atuou, nesse caso, de acordo com a perspectiva gramsciana como um "aparelho privado de hegemonia", ou seja, elaborador e difusor da ideologia dos grupos dominantes 3 .

Não se pode ignorar o fato de que a imprensa foi censurada ${ }^{4}$ e sofreu pressões econômicas. Por parte do governo, a possibilidade de perda da publicidade oficial e de subsídios, estratagema que foi utilizado para premiar ou punir os jornais de acordo com os interesses governamentais. Somado a isso, a acentuação da dependência econômica dos jornais em relação às verbas de origem estatal, em função do custoso processo de modernização dos parques gráficos dos grandes jornais brasileiros (SODRÉ, 1966; DUARTE, 1983). Por parte dos anunciantes privados, pressões indiretas, já que a maior parte da receita dos jornais era oriunda de publicidade de corporações nacionais e estrangeiras, alinhadas com o modelo econômico posto em prática a partir de abril de 1964 (BREGUÊS, 1978; SILVA, 2005).

Apesar dessas pressões, a imprensa não pode ser percebida como um mero instrumento nas mãos do governo e/ou dos anunciantes. Existiam também as influências próprias da mídia sobre os atores políticos, entre as quais interesses corporativos (donos de jornais) em jogo e compromissos com uma forma determinada de ordem econômica (o caráter empresarial e mercadológico e o modelo econômico defendido) que incidem na atividade jornalística e, de modo geral, iam ao encontro dos interesses e da visão de mundo das classes dirigentes. Efetivamente, excetuando-se o Última Hora, os jornais apoiaram o golpe. Isso sugere que, ao menos em linhas gerais e nos primórdios do regime, havia uma coincidência de pontos de vista entre eles e a coalizão civil-militar que derrubou João Goulart 5 . É óbvio que parte dessa confluência pode ter sido decorrente do

\footnotetext{
3 Existem várias referências a "aparelhos hegemônicos" nos escritos de Gramsci. Embora sempre apareça como fundamental para o exercício da hegemonia, ressaltando seu aspecto ideológico e sua função de "educar o consenso", a definição do conceito não é fixa, evoluindo com o tempo. Por esse motivo, opto por adotar a síntese de tal definição proposta por Carlos Nelson Coutinho (1992, p. 76), que entende que, para Gramsci, os "aparelhos privados de hegemonia" são "organismos de participação política aos quais se adere voluntariamente (e, por isso, 'privados') e que não se caracterizam pelo uso da repressão".

${ }^{4}$ Registre-se que a censura ocorreu muito mais sobre a atuação dos profissionais jornalistas do que pela linha editorial da grande imprensa, como observa Carla Luciana Silva. Em termos editoriais, os grandes veículos de informação sempre se mostraram partidários do golpe e da ditadura (SILVA, 2005, p. 53).

${ }^{5}$ Sobre uma análise mais profunda do papel da imprensa durante a preparação para o golpe militar, ver: STEPAN, 1975, cap. 5, p. 65-92. Sobre as críticas de cronistas de vários jornais à ditadura, ver: ALVIM, Thereza C. 0 golpe de 64: a imprensa disse não. Rio de Janeiro: Civilização Brasileira, 1979.
} 
medo, mas, atuando como um aparelho privado de hegemonia, interessado no estabelecimento de determinada ordem social, a grande imprensa apoiou conscientemente a ditadura e, noutras tantas, em troca de favores, atuou da mesma forma. Em todos os casos, findou por colaborar com a legitimação do regime.

Admitindo, então, a grande imprensa brasileira (jornais) como um aparelho privado de hegemonia, integrante da elite econômica, dependente da publicidade oriunda das grandes companhias estrangeiras e do governo e defensora de um projeto político liberal, interessava-lhe a substituição da ordem política nacionalista, representada por João Goulart, pela liberal, configurada pelo regime empresarial-militar. Por isso, ela não se furtou a contribuir na construção de uma imagem democrática para a ditadura.

Pode ser questionado o fato de como o jornalismo conseguiria exercer esse papel em um país como o Brasil que, na década de 1960, ainda exibia um elevado índice de analfabetismo, e onde as tiragens dos jornais eram pequenas. Porém, como afirma Smith (2000), a influência do jornalismo era comparativamente maior do que o seu número de leitores e sua influência ia além, apesar de ser um meio de comunicação típico das elites.

Dentre as seções dos jornais, uma em particular tem por missão explícita a discussão dos principais temas que envolvem o país: os editoriais. Neles, é feita a exposição dos pontos de vista do jornal, o que os tornam textos claramente opinativos, ao contrário das reportagens (a maior parte, ao menos), mesmo que isso seja apenas uma ilusão propagandeada. Ainda que as demais matérias também apresentem opiniões, é o editorial que sintetiza a orientação seguida pelas publicações. Embora seja de difícil precisão estabelecer qual o grau de atenção que o pequeno número de leitores de jornais dava aos editoriais ${ }^{6}$, pelas características expostas, a análise de seus enunciados pode ser

\footnotetext{
${ }^{6}$ Nos dias atuais, é fato a pouca atenção que os leitores dão aos editoriais. Estender essa conclusão aos anos 1960, no entanto, pode significar um descuido. A grande repercussão dos editoriais de capa "Basta" e "Fora", do jornal carioca Correio da Manhã, publicados respectivamente em 31 de março e $1 .^{\circ}$ de abril de 1964, leva à suposição de que lhes era dada uma importância relativamente maior. Além disso, os jornais 0 Estado de São Paulo e Jornal do Brasil possuíam uma página com um projeto gráfico definido para exposição dos seus editoriais (página 3 e 6, respectivamente). A supressão, após a edição do Al-5, dos editoriais referentes à política nacional, no primeiro, e supressão total da seção, no último, também são indicativos de que o próprio regime dava importância ao que neles era publicado. A exceção é O Globo que não possuía nem projeto gráfico, nem seção, nem periodicidade quanto à publicação de editoriais. No entanto, na maioria das vezes, mesmo que os temas não fossem de primeira ordem, sua publicação era feita na primeira página, o que já garantia uma visibilidade maior do que a das demais matérias do jornal.
} 
útil para a compreensão do processo de construção de um discurso de defesa da democracia em torno da ditadura empresarial-militar, que visava, por fim, legitimar a dominação de uma classe sobre outras.

Dado que uma análise extremamente ampla seria inviável, atentando para os limites da presente análise, a opção foi trabalhar com os jornais O Globo, O Estado de São Paulo e Jornal do Brasil, adotando uma seleção qualitativa das fontes7. Obviamente, a escolha de fragmentos dos editoriais dos jornais foi feita a partir de um objetivo de pesquisa previamente traçado. Como tal, se presta a críticas. Tal corpo documental também impede falarmos de uma visão homogênea sobre o golpe de 1964 e sobre a ditadura, ou de se chegar a uma síntese explicativa que possa constituir uma narrativa única. No entanto, em que pesem todas as diferenças editoriais entre os periódicos, havia uma característica em comum: eram jornais de empresas familiares, já com uma longa história, e com um passado de defesa de interesses políticos e econômicos próprios e próximos. A postura adotada era a de serem as vozes de seus proprietários, homens profundamente interessados e comprometidos com a derrubada do governo constitucional de João Goulart e com a construção da nova ordem que então se instaurava.

Há que ficar claro que esses discursos também não apresentavam uma homogeneidade retórica entre si. Embora os três jornais em questão fossem partícipes da coligação golpista, as diferenças são perceptíveis e exemplares da heterogeneidade do grupo unido em torno da deposição de João Goulart. Seu auditório era, além dos setores dominantes, basicamente, o todo amorfo das camadas médias. A diversidade desse

\footnotetext{
7 Como instrumental de análise, fundamentei-me no método apresentado por Laurence Bardin (1977, p. 105) para análise de conteúdos. Com base nesse modelo, procurei recortar as mensagens em unidades de registro. A busca foi a de "descobrir os 'núcleos de sentido' que compõem a comunicação e cuja presença, ou frequência de aparição podem significar alguma coisa para o objetivo analítico escolhido". Como o tema da pesquisa versa sobre a o uso da retórica da defesa da democracia em torno do golpe de 1964 e da ditadura, as unidades de registros consideradas são os "temas-eixo" ao redor dos quais são organizados os discursos dos jornais. Como tal, as temáticas de base fazem referência ao golpe e à ditadura ("revolução" nos termos apresentados) e à própria democracia. Em torno delas, surgem subtemas como comunismo, liberdades, entre outros. Paralelamente à definição das unidades de registro, foram delimitadas as unidades de contexto - que são fragmentos da mensagem, como, por exemplo, a frase ou o parágrafo em torno do tema - que, apresentadas ao longo do artigo, podem auxiliar na análise.
} 
grupo refletia no discurso dos jornais, indicando, enfim, a fragmentação da coalizão "revolucionária".

As visões expressas, também não são estáticas. Quanto a isto, O Globo pode ser considerado exceção, já que tendeu a manter-se ao lado do regime e do governo, mudando de opinião apenas quando esse mudava de estratégia. Já os jornais O Estado de São Paulo e Jornal do Brasil, embora defensores dos ideais "originais" da "Revolução", ao longo do tempo tornaram-se críticos do modus operandi dos governos militares. Mas um elemento era comum a todos: a suposta defesa da democracia.

É, pois, na heterogeneidade que devem ser buscadas as conexões que permitem identificar elementos de construção de sentidos, padrões comuns que orientam a elaboração do discurso jornalístico com relação à ditadura. Não se trata de procurar uma verdade que se encontra escondida nas entrelinhas do texto, mas uma tentativa de problematizar historiograficamente o discurso jornalístico.

As questões as quais a análise se propõe a responder passam, portanto, pela forma como o novo sistema de dominação que então se instaurava, contando com o suporte dos jornais, procurou fundamentar essa sua busca por legitimação baseada na defesa da democracia. Uma primeira intenção é fazer uma análise retórica dos discursos dos editoriais dos jornais, porque, sendo o objetivo do discurso a persuasão e o domínio da retórica, justamente, o domínio dos meios para se atingir a persuasão, essa análise poderá indicar como os jornais participaram desse processo.

Não se pretende, de modo algum, fazer uma análise que consiga abarcar todos os elementos constitutivos dos discursos dos editoriais. Uma proposta desse tipo, por si só, justificaria um trabalho particular e exigiria uma profundidade a que um artigo jamais poderia atingir. Contudo, os excertos selecionados se mostram representativos de um universo maior, denotando um caráter: a presença da democracia como formação discursiva predominante não só no discurso jornalístico, mas, principalmente, no

\footnotetext{
8 Ao longo deste artigo, o movimento civil-militar de março/abril de 1964 receberá, por vezes, a denominação de "revolução", "movimento revolucionário”, etc. O uso dos termos não tem qualquer caráter ideológico. Esta opção deve-se exclusivamente ao fato de ser esse tipo de denominação a que predomina ao longo dos editoriais dos jornais analisados. Procurou-se manter a designação expressa na fonte por se considerar que isto torna mais clara a leitura. Em todo caso, virão sempre entre aspas.
} 
imaginário político e social tanto das camadas médias e alta da sociedade, como também entre os militares, na década de 1960. E, de modo central, como o argumento da sua preservação foi usado na construção e manutenção de um projeto hegemônico de classe, de caráter elitista e excludente.

\section{A retórica dos jornais}

Na busca pela construção de um consenso junto às camadas médias e alta da sociedade, de modo que lhe servissem de base de sustentação, os donos do poder precisaram evocar e seguir, ainda que de forma não usual, determinados valores tidos como importantes para tais segmentos sociais. No imaginário desses grupos, uma formação discursiva que se apresentava como núcleo temático era a defesa da democracia.

A reiteração desse compromisso derivava de padrões de uma cultura política que ultrapassava as fronteiras nacionais. A forma democrática de governo contava com "prestígio" internacional e histórico, o que fazia com que o Brasil, como "nação democrático-liberal", agisse em sintonia com tais princípios. Esses "antecedentes" serviriam de "barreira" a uma dominação que se furtasse a fazer referências à democracia, em especial na segunda metade do século XX. Como reflexo dessa realidade, por ser um elemento fundamental para o seu auditório, a democracia também era uma formação discursiva central no discurso jornalístico. Mas essa comunhão de princípios não basta. Para que o discurso tenha efetividade, é preciso simular a existência de um sujeito coletivo.

\section{A simulação de um sujeito coletivo}

Para legitimar a sua função de perito e atingir o seu objetivo de persuasão, além de mostrar-se digno de fé, o locutor tem que construir a sua identificação com o seu auditório. Para isso, necessita apresentar-se como um igual, como alguém do mesmo grupo, que comunga dos mesmos interesses e que só se destaca pela função que lhe foi delegada de porta-voz do grupo ao qual pertence. Um dos meios de assim proceder é 
através da simulação de ausência do locutor e da identificação com a figura de um locutor genérico, que interpreta os fatos na sua “verdadeira dimensão histórica”. Essa estratégia faz com que o locutor não se apresente apenas como narrador, mas como enunciador universal que exprime a voz do saber, logo, como testemunha privilegiada dos acontecimentos, como porta-voz da história. Alguns fragmentos dos editoriais ilustram essa ideia9:

1. (...). A revolução foi obra da coletividade brasileira na sua totalidade, e o que a torna um dos momentos mais altos da nossa História é exatamente o ela ter sido uma determinação imperativa da consciência nacional. ( $O$ ART. $3^{\circ}$ do A. Institucional e o espírito da Revolução, p. 3, 1964)

2. (...). Somos uma Nação intransigentemente liberal democrática, e foi por isso que, como Nação, decididamente nos levantamos contra os que a toda força nos pretendiam arrastar para a órbita das ditaduras de "esquerda". (...). (O ART. $3^{\circ}$ do A. Institucional e o espírito da Revolução, p. 3, 1964)

3. Ficará claro que o Congresso terá aproveitado plenamente a oportunidade para dar um voto de confiança à Revolução que nos salvou, há cem dias atrás, de termos tombado na anarquia mais ignóbil, com o esfacelamento da Pátria. (VOTO de confiança, p. 6, 1964)

4. Experimenta o País uma sensação de desafogo com a eleição à Presidência da República do sr. marechal Costa e Silva (...). a coletividade nacional percebe perfeitamente que uma vontade mais alta entra agora a ter voz ativa nos negócios da República. (...) espera a comunhão brasileira que o presidente eleito, (...), use da sua autoridade para evitar que o sr. marechal Castelo Branco leve a bom termo o seu propósito de impor ao País uma Carta Constitucional que corresponda muito mais à sua maneira autoritária de encarar a problemática nacional do que às aspirações democráticas do nosso povo. (A MISSÃO do novo Presidente, p. 3, 1966) 5. (...). Já que a ultrapassamos [a crise entre o Executivo e o Legislativo], não a revolvamos. (...). Repetidas vezes O GLOBO tem insistido na necessidade de superarmos ressentimentos, sobrepor-nos a equívocos, nesta árdua hora que só deverá ser iluminada pela inspiração da paz, da harmonia, da conjugação de esforços e da mobilização de vontades visando à grandeza da Nação e à felicidade da família brasileira. (O ÚNICO Imprevisível, p. 1, 1966)

6. A reação - ou a não-reação - popular indica a presença de enorme receptividade potencial da opinião nacional a decisões grandes que realmente solucionem os magnos problemas do País. Portanto, não há lugar para gestos pequenos após o 13 de Dezembro. (...). (O SALTO e o atleta, p. 1, 1969)

Percebe-se, em especial nos trechos grifados, que o discurso jornalístico funciona sobre dois eixos: a construção de uma ilusão de exterioridade e neutralidade; em

\footnotetext{
${ }^{9}$ Ao longo de todos os fragmentos dos editoriais contidos neste artigo, quando não houver nenhuma menção em contrário, os grifos serão meus.
} 
paralelo, a quimera da interlocução. O efeito de exterioridade-neutralidade é útil por dar ao locutor um distanciamento que lhe permite a emissão de opiniões, encobrindo os seus interesses e sua atuação como aparelho privado de hegemonia. Segundo Bethania Mariani, isso ocorre porque o discurso jornalístico é uma modalidade de "discurso sobre". Um efeito desse tipo de discurso seria tornar em objeto aquilo do que se fala, o que possibilita produzir um distanciamento, um sentido de imparcialidade do narrador com relação ao próprio objeto. Distante, imparcial ou mesmo autoexcluído, o enunciador pode pautar temas, ditar caminhos, sem se revelar como parte diretamente interessada no que aborda.

Há que ficar claro que essa ilusão de neutralidade do discurso não é algo imanente na história da imprensa brasileira. Durante os anos 1950, com o ingresso do capital estrangeiro, o "modelo norte-americano" foi adotado de modo generalizado no discurso jornalístico nacional. Ocorreu, então, uma passagem de um jornalismo de tipo "políticoliterário", espaço de opinião e experimentação estilística, muitas vezes explicitamente ligado a grupos e partidos políticos, para um jornalismo dito "informativo", marcado por uma suposta neutralidade, independência e objetividade (RIBEIRO, 2000). Nesse sentido, como frisa Carla Luciana Silva (2005, p. 44) “A desvinculação formal de um partido político atende, exatamente a esse interesse [agir partidariamente no sentido de classe], pois o jornal não deixa de ser portador de 'opiniões', mas pode assim dizer-se 'independente"'.

Essa "neutralidade" finda por reforçar o seu caráter de "sistema perito", de que nos fala Luís Felipe Miguel (1999). Como tal, cria-se a ilusão de que o discurso jornalístico é onipresente, onisciente, objetivo, o dono da verdade, que apresenta os fatos "tais como são". Segundo Mariani (1998), essa forma de operar faz com que o discurso jornalístico funcione de modo semelhante a um discurso pedagógico autoritário, executando a mediação entre as informações e o seu público, mascarando a interpretação que é feita, imprimindo uma ilusão de objetividade jornalística. Por sua vez, o auditório torna-se um "leitor-aluno", que precisa da explicação imparcial que o jornal, como "sistema-perito" que "detém" um conhecimento privilegiado dos fatos, fornece. Agindo dessa maneira, o jornal "apaga” o que lhe convém, se põe acima dos conflitos 
sociais e oculta seus interesses particulares de defesa de um projeto com um sentido de classe autoritário e excludente. Especificamente, buscam seduzir a "opinião pública" de modo a torná-la crente, a produzir uma ilusão de consenso quanto à "capacidade" administrativa e, especialmente, "salvadora" do regime, e, em sentido oposto, produzem um dissenso quanto aos opositores da "Revolução". Logo, a afirmação da neutralidade apenas encobria sua atuação partidária.

Entretanto, o auditório não pode ser apresentado como um sujeito à parte, como mero ouvinte-passivo. É preciso promovê-lo a um lugar de decisão na estrutura política. Nesse sentido, no processo discursivo dos jornais criou-se, também, uma quimera de interlocução. Nesse processo, o auditório representado, no caso específico pelas designações “o povo”, “a Nação”, “o País” etc., como sustenta Mónica Zoppi-Fontana (1997, p. 93), “é definido como sujeito desta prática dialógica, que funciona como representação simbólica da prática política exercida por esse mesmo sujeito”. Seguindo essa lógica, “O País” foi quem “fez a revolução”, "se levantou contra a esquerda”, etc.

Além da ilusão de interlocução, de um "diálogo entre iguais", nessa "retórica do povo em ato", locutor e auditório tornaram-se "um" através de um “sujeito coletivo", um "nós inclusivo", de valor referencial equivalente a o Brasil, os brasileiros. Essa "união" foi personificada nos pronomes "nosso" e "nós”, mesmo quando oculto, mas presente pela conjugação do verbo na primeira pessoa do plural; nos substantivos "povo", "País", “Nação”, "coletividade”, “comunhão”, precedidos, ou não, de artigos definidos; e no uso de expressões como "coletividade brasileira", "coletividade nacional”, “comunhão brasileira”, “família brasileira”, “opinião nacional”, “povo brasileiro”. Ou seja, na tentativa de "seduzir" o seu auditório, o locutor precisa vinculá-lo a um todo "unicelular", personificado nas imagens de "povo-uno" e "nação-una”.

Esse "nós inclusivo", conforme Mariani (1998, p. 151), cria uma cumplicidade entre jornal e leitores, que os faz "partilharem" de um mesmo imaginário proposto pela forma de construção do discurso jornalístico. Engaja-se o leitor em uma mesma posição política, legitimando-se a função dos jornais como "porta-vozes" de "todo o povo". Em última instância, não é o jornal, mas o povo que fala. 
Dessa maneira, como meio de representação do sujeito o "nós" foi inclusivo, quanto ao auditório, e excludente, quanto ao locutor. Além disso, ele compreendeu tanto os que concordavam com o locutor, quanto os que se recusavam a concordar, estabelecendo um saber comum a "todos", pois o caráter unificador eliminou a possibilidade de existência do diferente. Como sustenta Zoppi-Fontana (1997, p. 95), o “nós”, “país”, o “povo”, o “o” e o “a”, mesmo que indefinidos, envolvem o leitor, barrando a existência de um diferente, excluem o adversário e dão o valor referencial de povo unido. O “país”, o "povo" etc. passaram a ser identificados com "brasileiros”. Ao mesmo tempo, a identificação do locutor com o "nós”, o "povo", o transformou no conjunto dos brasileiros. Como resultado, essa identificação exerceu caráter determinante na configuração do poder político pós-1964, porque universalizou os interesses de uma classe específica como se fossem do povo em geral, contribuindo, como já mencionado, na produção e reprodução do consenso social e reforçando o domínio de uma classe sobre outras.

\section{Discurso Bipolar (o Bem vs o Mal)}

Temos que o discurso jornalístico serve à disseminação das práticas discursivas de exercício do poder, porque, como assinalado no tópico anterior, ele trabalha de modo a impor algumas destas ao mesmo tempo em que silencia as antagônicas ou divergentes ao poder político dominante. Em complemento, na medida em que se positiva, se coloca como a única possível, com a opção da nação, a figura, a ação de alguém, deduz-se que os seus adversários são exatamente o oposto, o negativo, o incerto, o inimigo, o outro, o mal. Não há direito à diferença. A título de exemplo, esse caráter maniqueísta se mostra presente nas sequências destacadas abaixo:

7. (...) o JORNAL DO BRASIL mantém sua linha de coerência no combate ao Governo deposto e no apoio ao movimento civil e militar que o liquidou, para salvar o Brasil da desintegração, da comunização e da submissão nacional. (...). (O ATO Institucional, p. 6, 1964)

8. Se a Revolução não tivesse obtido a vitória, se os comunistas e seus aliados houvessem derrotado os democratas, que teria acontecido ao Brasil? Estaríamos mergulhados num banho de sangue, os pelotões de fuzilamento não descansariam, a Constituição teria sido abolida, o Congresso fechado e ninguém mais ouviria falar em liberdades públicas 
ou privadas. O Ato Institucional objetiva, precisamente, a impedir que os inimigos da democracia voltem a dispor de condições para atentar contra a liberdade e o regime. (A REVOLUÇÃO Consolidada, p. 1, 1964)

9. (...) Não foi, com efeito, necessário um tiro sequer, não se exigiu uma só gota de sangue para que se despovoasse o ambiente nacional dos energúmenos encarregados de desfechar no Brasil a guerra pela revolução vermelha. Mansamente se vão higienizando as posições políticas, quietamente se vão afastando dos cargos administrativos os corruptos e os corruptores e com o esvaziamento dos pelegos vermelhos no campo sindical voltam a reinar a calma, a ordem e a reflexão nos meios trabalhistas. (...). (A FORTE personalidade do novo líder, p. 3, 1964)

Nota-se, através dos fragmentos, que os rituais discursivos que constituíam a prática cotidiana dos jornais encontravam-se submetidos a uma lógica cristã ocidental marcada pela oposição Bem vs o Mal. Tomando as reflexões de Alain Badiou (1995) como referência, é possível dizer que essa sujeição é resultado da própria construção histórica do discurso jornalístico - de modo geral, e do brasileiro, em particular - em torno de uma ética dos direitos humanos, tidos como evidentes, como garantia de igualdade nas sociedades, marcada, entre outros elementos, pela defesa da propriedade, das liberdades fundamentais (expressão, opinião, escolha democrática de governos), da ordem, da moral cristã e pela ideia de punição a tudo que ameace esses direitos, a ideologia capitalista e/ou a moralidade cristã ocidental.

Bethania Mariani relembra que a primeira lei de imprensa do Brasil, datada de 1824 e que tomou por base a lei portuguesa de 1821, previa como abusos ou delitos da imprensa falar contra a religião católica romana, o Estado, os bons costumes (a moral) e os particulares (a propriedade). Ou seja, essa lei impedia que se dissesse qualquer coisa que se opusesse à ideologia ocidental cristã. Nesse sentido, em parte por temer punições, em parte por afinidade ideológica, o discurso jornalístico - perito e locutor imparcial da verdade dos fatos -, ao defender a ética dos direitos do homem como garantia de igualdade, veicula os sentidos que interessam aos dominantes.

Para agir dessa forma, segundo Mariani, o discurso jornalístico se encontra atravessado "por um já-dito sobre o Bem que se constitui em um já-ouvido no campo dos leitores, o que engendra um efeito de reconhecimento, ou consenso intersubjetivo". Como consequência, configura-se uma distinção entre o campo do Mesmo e o campo do Outro, em que estar no campo do Mesmo é partilhar, simbolicamente, dos valores do 
Bem, “é considerar 'evidentes' e 'naturais' os sentidos que se alinham à sustentação/legitimidade do sujeito de direito ou dessa ética dos direitos do homem" (MARIANI, 1998, p. 83), e estar no campo do Outro é fazer parte do campo do Mal, do que é negado. O Mal, no entanto, é necessário para a própria construção desse Bem. Sem a identificação desse Mal não teríamos como definir o que é o Bem. Ou, como apontou Badiou (1995, p. 24), por essa ética dos direitos humanos, “o Mal é aquilo a partir do que se dispõe o Bem, não o inverso". Os direitos humanos são, portanto, o direito ao não-Mal.

Seguindo-se essa lógica, nota-se nas sequências destacadas que o Mal era claramente identificável, enquanto que o Bem, nem tanto. Na argumentação, era feita a seguinte relação: Mal era tudo o que pertencia ao campo do Outro, do contrário, o que devia ser rejeitado (o comunismo, o governo João Goulart); e Bem, - que incluía o locutor e seu auditório -, era o natural, o indiscutível, o arraigado, o consenso (tudo que se volta contra o comunismo, contra a ordem deposta, a democracia, em última instância). Em função disso, estar no campo do Mesmo, partilhar dos valores do bem, ou como aponta Badiou, do não-Mal, seria defender a moral, a propriedade e a cristandade. Qualquer discurso contrário a essa lógica e que pusesse em risco a ética ocidental dos direitos do homem, era negado. Em outras palavras, nesse discurso maniqueísta, quanto mais se rejeitava o pensamento do Outro - inimigo dos valores ocidentais - mais afirmava-se uma identidade brasileira no campo do Mesmo, filiada ao imaginário ocidental cristão, à ideologia capitalista. Construía-se um consenso em torno dessa perspectiva, apresentada como inexorável.

Por conseguinte, a luta da democracia vs comunismo aparece caracterizada como a luta do Bem vs o Mal. Não era um enfrentamento político, um conflito entre classes, mas uma luta moral na qual o Bem deveria vencer e expulsar o Mal.

Em resumo, construído dessa forma, o discurso cotidiano dos jornais procurou criar uma "ilusão de consenso" quanto ao regime e aos opositores, com o objetivo de reforçar o "poder simbólico" dos dominantes. Durante todo o tempo, esse discurso estava marcado por um consenso intersubjetivo sobre o Bem, quando este - embora só definido a partir do que é o Mal - era tido como evidente. Contudo, ocorreram alterações quanto à definição do que era o Mal, ao longo do tempo. Como salienta Zoppi-Fontana 
(1997, p. 97), a construção do "sujeito coletivo" não é perene e com o passar do tempo surgem vozes dissonantes, como sugerem os excertos a seguir:

10. (...). Haveria efetivamente no País ambiente para eleições? E estava a Revolução preparada para enfrentar uma ampla consulta popular? A resposta é forçosamente negativa. (...). Os sacrifícios exigidos pela Revolução ao povo brasileiro teriam por força de impopularizar essa mesma Revolução. Foi o que o sr. marechal Castelo Branco esqueceu ao convidar o povo a comparecer às urnas. Sabíamos que, no momento, os sacrifícios pesariam mais no ânimo das massas do que os benefícios que apenas principiam a atingi-las. Em que pese s. exa., que insistiu sempre em encarar os pleitos como atos de âmbito puramente regional, a Revolução estava em causa. E o veredictum popular não podia ser-Ihe favorável. (ELEIÇÕES realizadas, p. 3, 1965)

11. (...). O mal não está nas instituições e não será mutilando a Constituição que o sr. marechal Castelo Branco acabará com as crises que continuam enfraquecendo o seu governo. (...). (EMPATE impossível, p. 3, 1965)

12. (...). O Governo de inspiração revolucionária, ao editar anteontem o seu Ato Institucional n. $^{\circ}$ 2, não se limitou a lançar mão de recursos e poderes excepcionais considerados, de seu ponto-de-vista, indispensáveis a debelar a crise aguda, que se reabriu nas instituições. $O$ Governo extrapolou da missão que lhe compete e provocou, a olhos vistos, um retrocesso político que desmente, senão anula, os objetivos democráticos de seu programa de recuperação nacional. (DIREITO de defesa, p. 6, 1965)

13. O Governo revolucionário, que atravessou o seu período mais difícil sem afetar a liberdade dos jornais, decidiu-se, finalmente, ao apagar das luzes, por uma iniciativa de caráter antidemocrático e de duvidoso alcance prático. Se deseja, porém, teimosamente, insistir no erro, assuma então a exclusiva responsabilidade e seu ato e decrete o diploma com que procura ferir um direito fundamental de toda sociedade livre. $O$ Congresso é que não deve associar-se a essa aventura sinistra e ditatorial, mesmo porque não há um congresso verdadeiramente livre num regime em que os jornais são submetidos a medidas de restrição e coerção. (...). (RESPONSABILIDADE, p. 6, 1967)

Ainda que as críticas mais incisivas tenham ficado restritas aos discursos do Jornal do Brasil (fragmentos 12 e 13) e d'O Estado de São Paulo (fragmentos 10 e 11), percebe-se que ocorreu uma transfiguração com relação ao Mal, que passou a ser associado à política do governo. Se, por um lado, essa mudança evidencia a fragilidade da coalizão civil-militar no poder e as oposições internas que então surgiam, por outro, essa oposição fica restrita ao rumo adotado pelos governos militares, e nunca é direcionada aos "ideais originais" da "Revolução", que permanecem como a personificação do Bem. 
Desde os momentos iniciais do regime já eram evidentes as divisões no interior da coalizão golpista. A oposição da UDN à indicação de José Maria Alkmim, membro do PSD mineiro, para vice de Castelo Branco; a pressão dos militares de "linha-dura" pela a prorrogação do prazo para a cassação de mandatos e suspensão de direitos políticos; a resistência de Castelo Branco em cassar os direitos políticos do ex-presidente Juscelino Kubitschek e em prorrogar o seu mandato; e a mudança da data da eleição do sucessor de Castelo foram questões que geraram discussões e divisões no interior da coalizão golpista ao longo do tempo. Essa perda do consenso inicial se reflete nas modificações na produção do discurso, gerando variações no valor referencial do "nós" (divisão entre os “enunciadores", que foram excluídos do coletivo de identificação). Desapareceu o consenso e surgiu o adversário. Já não havia o “todos”, “o Brasil”, “os brasileiros”, e o "nós" deveria decidir com qual Brasil se identificar. Essa transformação mostra como a construção do "sujeito coletivo" é sempre precária e ameaçada pelo confronto ideológico, assim como é vulnerável a ilusão de consenso. Apesar disso, não se altera a figura do inimigo maior, as críticas à política do governo Castelo Branco não se comparavam ao perigo representado pelo comunismo.

\section{Valores coletivos}

Segundo Osakabe (1999), o ato de argumentar visa fazer com que o ouvinte não apenas se inteire, mas principalmente que aceite a imagem que o locutor faz do referente. Esse objetivo torna o ato argumentativo diverso do ato de informar, porque interessa ao seu agente mais o engajamento do ouvinte em relação à sua imagem sobre o referente do que a transmissão de determinada mensagem.

Para conseguir esse engajamento é preciso que o ato de argumentar parta de suportes que dificultem essa rejeição. O auditório não é totalmente passivo em sua relação com o locutor e, em certos momentos, "impõe" a este o atendimento a determinadas significações. O locutor necessita, portanto, conhecer o auditório para, “atendendo-o", persuadi-lo. Face à essa constatação e por ser voltado para a classe média, o discurso dos jornais em estudo precisou invocar valores considerados como indiscutíveis, fundamentais e aceitos por ela para poder persuadi-la e não ser rejeitado. 0 
uso de determinadas significações permite, então, a formulação/reafirmação de algumas hipóteses. Com esse objetivo, a título de exemplo, destacam-se algumas expressões contidas nas sequências discursivas abaixo:

14. (...) que nobreza maior poderíamos desejar num homem público do que esta de subordinar-se, nas democracias, à vontade popular, desde que legítima, desde que justa, desde que moral, desde que salvadora? (UM IMPERATIVO da consciência revolucionária, p. 3, 1964)

15. (...). Nesta hora, quando o interesse nacional levou o Presidente Castelo Branco a editar o Ato Institucional n. ${ }^{\circ}$, queremos deixar registrada a nossa convicção de que o ideal democrático de nossa gente não será esquecido e a 15 de março de 1967, quando deixará de vigorar o referido Ato, o País, inteiramente restaurado, voltará ao pleno e mais perfeito exercício do regime de sua preferência. (O EDITO de Brasília, p. 1, 1965)

16. (...). Analisado, porém, do ângulo político e dos supremos interesses da nacionalidade, impõe-se considerar que se as Forças Armadas têm o direito de serem respeitadas, (...), também é verdade que o precedente da cassação dos direitos políticos de um deputado federal, com a conseqüência do mandato eletivo, poderá muito bem afetar no futuro o próprio Congresso Nacional, (...). (O STF entre os militares e a Câmara, p. 3, 1968)

Nas sequências acima, aparecem com destaque os vocábulos "interesse nacional”, "supremos interesses da nacionalidade" e "vontade popular". A primeira característica a salientar sobre tais termos é que não sendo possível estabelecer uma referência universalmente aceita, eles se prestaram a abusos ${ }^{10}$. Todos, contudo, faziam referência a um fim. Impreciso, por certo, mas inconteste, necessário, pelo ponto de vista dos jornais, que exigia ser cumprido e não se punha em discussão. Aos periódicos, esse recurso era útil na busca do estabelecimento de um consenso sobre o sentido do que era apresentado aos leitores (a "vontade da Nação"). Como resultado, reforçavam o "poder simbólico" dos dirigentes e contribuíam para a reprodução da dominação.

Esses termos têm sentido de valores morais e, como dito anteriormente, ligados à defesa de uma ética ocidental cristã. Como os discursos em análise não tinham por meta informar, mas persuadir o auditório das imagens construídas pelos jornais, esse uso mostrou-se promissor e, por isso mesmo, tornou-se recorrente. Com esse objetivo, de modo geral, o fim desejado e inconteste foi associado à nova situação. E como se tratava de um interesse com caráter "único", tal como na simulação do "sujeito coletivo",

\footnotetext{
${ }^{10}$ Cf. FREGE, Gottlob. Citado por MARIANI, 1998, p. 110.
} 
eliminou-se a existência de um querer diferente, negou-se a voz do outro. Ou, em outros termos, a eliminação do "querer diferente" foi fundamental para a instituição da ficção da "vontade geral", que não era a vontade da maioria, mas a vontade "de todos". Contra esse Outro, inimigo, reafirmava-se a identificação do brasileiro à ética ocidental cristã.

No entanto, como afirmado, o auditório não é totalmente passivo na sua relação com o locutor. Referências nesse sentido são notadas nas sequências discursivas abaixo:

17. (...) o povo sabe perfeitamente o que deseja da revolução: legalidade, democracia, tranquilidade para o trabalho, paz de espírito, melhores e mais justas condições de vida sem nenhum prejuízo de liberdade. (...). (DECISÃO urgente, p. 6, 1964)

18. Mas o poder revolucionário ainda se autolimita quando estanca o seu alcance na fronteira dos direitos individuais. (...). É certo que a Revolução tem o máximo de poderes, menos o de violentar as franquias e liberdades do indivíduo como indivíduo, conquistas que não resultam de circunstâncias de Governo nem constituem privilégios, mas já identificam os próprios fundamentos da vida civilizada. (O ATO Institucional, p. 6, 1964)

19. O Governo terá que identificar-se com a vocação democrática dos brasileiros, devolvendo ao povo, no menor prazo possível, os instrumentos para o correto exercício do sistema democrático de vida, o único que aceitamos por tradição, formação e convicção. (...). (PODERES e responsabilidades, p. 6,1965 )

20. (...). Nesta hora, quando o interesse nacional levou o Presidente Castelo Branco a editar o Ato Institucional $n .^{\circ} 2$, queremos deixar registrada a nossa convicção de que o ideal democrático de nossa gente não será esquecido e a 15 de março de 1967, quando deixará de vigorar o referido Ato, o País, inteiramente restaurado, voltará ao pleno e mais perfeito exercício do regime de sua preferência. (O EDITO de Brasília, p. 1, 1965)

21. (...). E a Revolução só será útil e benéfica na medida em que contribuir para sanear e disciplinar a vida política nacional sem alterar nem banir as normas tradicionais por que se tem regulado e edificado até aqui o espírito democrático brasileiro. (O NOVO Ato Institucional, p. 3, 1965)

22. (...). É natural que o País, que por várias vezes já se creu no caminho da normalização político-institucional, não se sinta vivendo em estado de segurança, já que o Governo insiste em mantê-lo num suspense continuado, que envolve até mesmo as figuras de alguns líderes com altas responsabilidades na vida pública deste momento. (...). (RETROCESSO, p. 6, 1966, grifo do autor)

Percebe-se o uso frequente de termos que fazem referência a princípios tidos como incontestáveis, naturais. Isso ocorre justamente porque o leitor não é totalmente passivo nessa relação. Por essa razão, os "interesses de uma classe específica”, embora 
visem reforçar o seu domínio, o seu "poder simbólico", para serem aceitos precisam que o locutor faça referências a significações consideradas aceitas e assimiladas pelos ouvintes. Como salienta Haquira Osakabe (1999, p. 67), o desconhecimento dessas significações pode levar o ouvinte a simplesmente recusar o discurso. Por conseguinte, em um processo de persuasão, ao admitir que tais princípios seriam imprescindíveis ao seu auditório, os locutores, para serem dignos de fé, não poderiam deixar de vincular os seus discursos e as ações do governo a eles.

Entre as significações fundamentais destacadas, "direitos individuais", "franquias e liberdades do indivíduo", "liberdade" e "legalidade" estavam ligadas a valores nitidamente "universais" e aceitos como conquistas da sociedade moderna. Por isso, não poderiam ser ignorados. Outros como: “tranquilidade para o trabalho”, "paz de espírito”, “melhores e mais justas condições de vida”, “normalização político-institucional”, faziam referência a objetivos que a sociedade brasileira estaria buscando e que, supostamente, não seriam alcançados pelo caminho adotado até então. No entanto, é a presença dos termos "democracia”, "espírito democrático brasileiro”, "ideal democrático de nossa gente", "vocação democrática dos brasileiros", "sistema democrático de vida", que sugere a importância e a predominância da "democracia” no imaginário social e político do Brasil nos anos 1960.

Concluindo, embora o locutor tenha a "ilusão discursiva" de ser a fonte do sentido e de ter o domínio daquilo que diz, como afirma Fiorin (1988), o discurso é uma criação coletiva, porque é a visão de uma classe vinculada a uma estrutura ideológica determinada e condicionada, em parte, pelo próprio auditório. Contudo, nunca é demais salientar que todas essas expressões pertencem ao campo da ética cristã ocidental dos direitos humanos que tem por objetivo último preservar o status quo de uma elite dominante.

\section{A democracia como princípio}

O discurso finda por ter uma efetividade social, na medida em que os valores difundidos se tornam posições políticas cotidianas do auditório. Para tal, é preciso perceber a pré-disposição do auditório com relação à recepção e aceitação de certa visão 
de mundo. É nesse sentido que se destaca o uso da "democracia" como o elemento discursivo predominante no discurso jornalístico. É ela que contribui de maneira decisiva para a construção do consenso em torno do projeto de dominação que chegava ao poder. Isso se torna ainda mais claro nos fragmentos abaixo, principalmente através da transformação da "democracia” em adjetivo de uso recorrente:

23. (...). O que a revolução objetivou foi dar uma resposta democrática aos problemas e impasses que a conspiração comunista colocava em termos de atentado à legalidade e à consciência democrática, pacífica e cristã da Nação brasileira. (...). (JDECISÃO urgente, p. 6, 1964)

24. (...). A Legalidade Revolucionária e Constitucional - o Ato e a Carta Magna - é o fundamento do Poder Político da Revolução e do Presidente da República. E sem esse fundamento os inimigos da Revolução Democrática só poderiam ser eliminados pela força. (O BRASIL não voltará à corrupção e à subversão, p. 1, 1965)

25. (...). A Nação habituou-se a ver na conduta do Marechal Castelo Branco a constante preocupação de não ferir de morte o regime democrático e as garantias individuais. (DIREITO de defesa, p. 6, 1965)

26. (...). Dos numerosos pronunciamentos do Presidente inferia-se 0 propósito maior de criar para o Brasil um instrumento de estabilidade política a longo prazo, plataforma de onde o País marcharia para a conquista do desenvolvimento econômico, até que os dois termos da equação nacional se fundissem num modelo exemplar de democracia representativa. (PROCESSO Revolucionário, p. 6, 1966)

27. Ousaríamos afirmar que o projeto assinala o fim do liberalismo clássico no Brasil e o início de uma ordem jurídica mais condizente com os tempos novos, caracterizados em toda parte pelo fortalecimento do Executivo como o demonstram as instituições vigentes nas principais democracias ocidentais. (FIM do Falso Liberalismo, p. 1, 1966)

Segundo Fiorin (1998, p. 127), “Existem objetos-valor que adquiriram tal envergadura no transcurso da história, que as forças da reação não estão em condições de rechaçar ou difamar sem prejuízo para sua campanha. (...)". Não tendo, pois, como repeli-los, nota-se que nas sequências destacadas ocorreu a redução da extensão, ou mudança semântica, de alguns deles. Como efeito, eliminaram-se possibilidades de outras interpretações. Por exemplo, consciência ficou limitada à "consciência democrática, pacífica e cristã da Nação brasileira"; democracia à "democracia representativa", “democracias ocidentais"; legalidade à "legalidade Revolucionária e Constitucional”, regime a "regime democrático". Em um discurso que tinha por uma das características a oposição “democracia vs comunismo", a limitação de "democracia” ao “cristianismo", ao 
“ocidente", e do "regime" à democracia impedia qualquer possibilidade de associá-la ao opositor. Estabeleceu-se uma impossibilidade semântica. Além disso, a redução da legalidade à "revolucionária" demarcava um terreno de possibilidade. Ainda que pudesse haver outros tipos, apenas um deveria ser seguido: a "revolucionária". O termo “constitucional” restringia ainda mais essa possibilidade. Porém, em função de ser, também, um princípio fundamental para o auditório pode indicar um limite “desejável” à ação dita "revolucionária".

Contudo, o que é mais marcante é a contínua associação à democracia. Quando não se estava falando propriamente dela, com as reduções de extensão consideradas necessárias, ela estava sendo usada como adjetivo. O uso desse adjetivo legitimaria os substantivos.

Percebe-se, pois, que no processo de reordenação da situação, visando à legitimação do referente, o locutor fez uso constante de termos associados a "valores coletivos". De modo geral, todos os "valores" em destaque nas sequências até aqui mencionadas têm um caráter democrático. Na medida em que, além da recorrência, o locutor insistia em atender a essa imagem "democrática", reforça-se a tese de que essa imagem não era mera criação de um agente externo, mas inerente ao próprio auditório. Por isso, em sua tentativa de persuadi-lo, os jornais não poderiam deixar de vincular os seus discursos a ela. Negar esse pressuposto inviabilizaria o diálogo, dificultaria o estabelecimento do consenso sobre o sentido do mundo que o regime queria impor e tornaria mais custoso o reforço do "poder simbólico" dos dirigentes e, em consequência, a própria dominação. É nesse sentido que o discurso jornalístico do período vinculava os "supremos interesses" do "povo brasileiro" à preservação de um determinado tipo de “regime democrático", configurado na "Revolução", e apresentava os opositores do regime como "inimigos" da "democracia".

Tendo por inquestionável que parte da população acreditava na manutenção de princípios democráticos, supõe-se que a imagem que ela fazia de um regime ideal seja a de um regime com essas características. Nesse sentido, a necessidade de legitimação democrática por parte da ditadura exigia a sua caracterização/associação à democracia. Se a democracia era um objetivo nacional permanente e se o Estado era um 
representante desse objetivo, ele passava a ser legítimo; se seguia de conformidade com princípios democráticos, que eram da vontade do povo, passava a também derivar dessa vontade. É o que se verifica nos fragmentos a seguir:

28. Para defender a democracia, preservar as instituições e continuar existindo, as Forças Armadas se encarregaram, com amplo apoio popular e político, de afastar do Governo aquele que não soubera aproveitar as esplêndidas oportunidades que the havia reservado o destino. (...). (A VEZ do Congresso, p. 1, 1964)

29. Vem-se revelando até aqui extremamente feliz o movimento revolucionário destinado a restabelecer no País a normalidade democrática e a pureza republicana. (...). (A FORTE personalidade do novo líder, p. 3, 1964)

30. (...). A atitude básica que norteia o Presidente Castelo é de que a Revolução veio para reintegrar o País na democracia. (...). (AUTORIDADE, p. 6, 1964)

31. Discordamos desde a primeira hora das primeiras tentativas de "legalização" do regime; (...) discordamos, numa palavra, da perigosa ficção de que o País voltará à "normalidade democrática"; (...). (O CAMINHO a seguir, p. 3, 1965)

32. O endereço da nova Carta é um só: preservar os fundamentos democráticos impedindo que, sobre estes, se erga a anarquia ou a tirania. (O ENDEREÇO da Carta, p. 1, 1966)

33. É inócuo falar todo dia em democracia, quando não estão em vigor práticas democráticas nem há exercício convencional da atividade política. (...). (UM IMPASSE, p. 6, 1968)

34. (...) a primeira constatação a fazer é esta: os que falam em ditadura não conseguem provar o que sustentam. Um país onde a imprensa é livre e onde se vota com plena liberdade é um país democrático. (ANÁLISE do pleito, p. 1, 1968)

Percebe-se que havia uma tentativa inicial de associação do regime e de suas ações à democracia e, em particular, da "Revolução" ao salvamento da democracia. Os jornais se apresentam como divulgadores dessa nova situação. Ao longo do tempo, ocorreu uma alteração nesse processo. Embora a "Revolução" e, principalmente, os seus objetivos, continuassem sendo associados à democracia, a oposição do Jornal do Brasil (fragmentos 30 e 33) e, em especial, a d'O Estado de São Paulo (fragmentos 29 e 31) passaram a associar os caminhos escolhidos pelo governo militar à oposição à democracia. Constata-se, portanto, que mesmo quando se "excluía" do governo - nunca do regime - o seu caráter "democrático", a democracia continuava a ser apresentada como valor fundamental. Essa, contudo, não era uma característica apenas dos discursos dos jornais. Mesmo a oposição detectada nas sequências d'O Estado de São Paulo que 
denunciava a "perigosa ficção" legalista de Castelo Branco de querer fazer retornar, com rapidez, a "normalidade democrática", sugere a opção do presidente e de seu grupo pela estratégia de preservação de determinados preceitos democráticos, embora reduzidos em suas características clássicas.

Em síntese, a análise dos editoriais dos jornais sugere que a democracia era uma formação discursiva dominante no imaginário político e nos discursos jornalísticos do pós1964. Tanto o governo quanto os jornais acreditavam que, para a população de forma geral, e para o público leitor dos periódicos, em particular, a preservação de princípios e instituições associados à democracia era de fundamental importância para a legitimação do regime e, em consequência, para a consolidação da sua hegemonia. Por isso, a retórica dominante adotou esse elemento por temática. Contudo, não é possível limitar esse procedimento apenas à retórica. A prática, ainda que de maneira tortuosa, teve que assumir o exercício desses elementos.

\section{A "democracia tutelada"}

Poderia ser argumentado que as menções à democracia seriam simples retórica ou uma falsificação que nada tinha a ver com as noções teóricas clássicas e que procurava esconder os verdadeiros objetivos. Mas, mesmo que a prática autoritária negasse as caracterizações democráticas presentes nos discursos dos jornais, como afirma Luiz Vítor Azevedo (1987, p. 69), a retórica empregada pelos jornais “não deve ser vista como simples forjadora de metáforas, mas principalmente como instrumento de persuasão, ou seja, a ressonância, nos adeptos ou no público em geral, é basicamente de adesão". O objetivo desse processo de persuasão era contribuir na legitimação do novo regime. Além disso, segundo entendimento de certos analistas, uma parte dos novos detentores do poder, entre eles grupos militares, propunha um "respeito" às normas e instituições tradicionais da democracia, ainda que sob "tutela". Como salienta Bolivar Lamounier (1986, p. 289, grifo do autor),

(...). Skidmore, por exemplo, escreve que os revolucionários de 1964 "nunca faltaram com seu empenho verbal" e sempre conservaram a intenção de um eventual retorno à democracia liberal; mas também 
observa que os próprios militares da "linha dura" evitaram repudiar publicamente a fé da elite política brasileira nos princípios liberais. (...).

Por causa dessa "fé pública" da elite política nacional nos princípios liberais, uma ruptura total não seria interessante. Por esse motivo, não teriam como negar a democracia de modo radical. Para assegurar a adesão, melhor seria preservar instituições típicas do sistema que diziam querer respeitar e justificar as suas alterações na necessidade de modelar um novo regime político livre dos vícios do passado recente. Livrar-se desses "vícios" significava uma "democracia aperfeiçoada”. É o que se nota nos fragmentos abaixo:

35. O Congresso certamente não faltará ao Governo com a colaboração que mais uma vez lhe é pedida para dar continuidade ao processo instaurado no País a 1 de abril de 1964 e cujos fins são de essência democrática, por mais que suas formas transitórias se afastem das linhas clássicas do regime em estado de normalidade. (...). (ETAPA Final, p. 6, 1965)

36. (...). Revolucionários que somos, admitimos o recurso a medidas de exceção uma vez que só os poderes emanados das mesmas podem permitir-nos a realização dos anseios do Movimento de março, isto é, a construção de uma sociedade democrática e próspera, imunizada contra os males da corrupção e as falsas seduções de todas as ideologias subversivas. (...). (O INEVITÁVEL aconteceu, p. 3, 1965)

37. Salvaguardar a essência democrática mesmo à custa do sacrifício de certos ritos - confundidos tragicamente pelo chamado "bacharelismo" com aquela essência - é, em síntese, o que se espera da Revolução. (...). (A HORA de Castelo, p. 1, 1966)

38. (...). A Constituição que o Governo propõe há de ser entendida, pois, como um estatuto revolucionário, que entrega à Revolução todos os poderes por ela reclamados para sanear, disciplinar e organizar a vida nacional, em detrimento, ainda que temporário, da ideologia democrática. (ESTATUTO Revolucionário, p. 6, 1966)

39. O gosto amargo da desordem insuflada e organizada pelo próprio Governo, naqueles tristes anos em que estivemos à borda do caos, fez com que o Brasil recebesse de braços abertos a intervenção saneadora dos militares e compreendesse a adoção das medidas excepcionais, que interromperam o fluir de nosso processo democrático. (...). (FORÇAS Armadas, p. 6, 1968)

Apesar da tentativa declarada de perpetuar a associação do regime com a democracia, percebem-se indicações de que não se tratava de uma "democracia formal" e que a concretização da "democracia" ficava sujeita a outros fatores. Era um fim maior, um "futuro", que seria democrático, que ditava o caminho a seguir. 
As menções aos objetivos de "salvaguardar a essência democrática" à custa do “sacrifício de certos ritos" ou em "detrimento temporário da ideologia democrática”; ou referências às "formas transitórias" do processo instaurado com a "Revolução", que se afastavam das "linhas clássicas" do regime democrático, mas cujos fins seriam de "essência democrática”, ou ainda à admissão do recurso a medidas de exceção para a construção de uma "sociedade democrática e próspera" e o reconhecimento de vivermos um período anormal que levaria a poderes excepcionais, indicam que a democracia continuava sendo apresentada como desejada. No entanto, reduzia-se a sua extensão de acordo com os objetivos dos donos do poder e fazia-se com que ela ficasse submetida a outros fatores que, por sua vez, também eram apresentados como "democráticos". O que se percebe, contudo, é que as exceções apresentadas eram postas como fruto da missão do regime de salvar a própria democracia. Defendia-se um paradoxo: restringir a democracia para salvar a própria democracia. O fazer do regime era, pois, apresentado como um fazer defensivo, cujo objetivo seria o de livrar o país do "comunismo", da “corrupção" e da "subversão", associados à situação anterior à "Revolução".

Portanto, a democracia deveria propiciar a paz interna, a justiça social e o fortalecimento da segurança nacional, mas as liberdades democráticas não poderiam se voltar contra a nova ordem. Ou seja, para proteção da "Revolução" poderiam ser restringidos direitos e liberdades. Surgia uma relação de dependência na qual a democracia dependia do arbítrio. Logo, quando se falava em democracia, não significa que se estivesse falando de uma "democracia formal". Na verdade o que se pretendia era uma democracia "aperfeiçoada", "restrita" ou, como denominam Stepan (1975, p. 170) e Maria D’Alva Gil Kinzo (1988, p. 218), uma “democracia tutelada”.

Consciente de que, para estabelecer e manter a sua hegemonia, precisava construir um consenso junto a determinadas parcelas da sociedade, a facção militar “castelista” que predominou nos primeiros anos do regime não tinha, segundo Kinzo (1988, p. 218), a intenção de instaurar um regime tipicamente militar-autoritário. Nesse sentido, procurou instalar um processo de “democracia tutelada". Esse projeto consistia, basicamente, no estabelecimento de um regime híbrido que mantinha procedimentos constitucionais junto com os poderes arbitrários do executivo. Seu objetivo declarado - 
não necessariamente o real - seria o exercício direto do poder pelos militares pelo tempo necessário à consolidação das bases de um sistema político seguro e estável, protegido contra a subversão, a corrupção e o comunismo, para, só depois, devolver o poder aos civis. É possível afirmar que o discurso dos jornais reproduzia essa mesma lógica.

Em linhas gerais, esse projeto garantiu poderes excepcionais ao executivo, porém, o "constrangeu" a "seguir" as normas democráticas que ele preservou e que dizia defender; restringiu os poderes do legislativo e do judiciário ${ }^{11}$, mas os manteve em atividade; sustentou eleições para presidente, sendo que indiretas, e eleições periódicas para o legislativo, sob controle; conservou, inicialmente, os partidos, após o expurgo dos parlamentares indesejáveis; extinguiu-os, por fim, mas elaborou um novo sistema partidário; e preservou, a princípio, a Constituição de 1946, contudo, impôs-lhe alterações. Além dessas características, a concretização de tal projeto não excluía necessariamente a violência, como atestam inúmeros casos de prisões sem culpa formada, interrogatório sob tortura e mortes de oposicionistas registradas no período, práticas inerentes à denominada "Operação Limpeza", que, sob a guarita da tese de defesa da segurança nacional, e objetivando eliminar possíveis focos de oposição (política, econômica, psicossocial e militar), investigou e expurgou funcionários da burocracia civil e militar, suspendeu mandatos e cassou direitos de políticos, e praticou atos que atentavam contra as liberdades e os direitos constitucionais ${ }^{12}$ (ALVES, 1984, p. 56-71).

Destarte, como regime autoritário queria o controle social, mas precisava de consentimento quanto à sua dominação. No mundo moderno, de forma geral, e para o regime empresarial-militar brasileiro, em particular, a manutenção das normas e

\footnotetext{
${ }^{11}$ Sobre a preservação do poder Legislativo durante a ditadura como uma necessidade do processo de legitimação do regime, ver: VASCONCELOS, Cláudio Beserra de. A preservação do legislativo pelo regime militar brasileiro: ficção legalista ou necessidade de legitimação? (1964-1968). 2004. 334f. Dissertação (Mestrado em História Social) - Programa de Pós-graduação em História Social, Universidade Federal do Rio de Janeiro,, Rio de Janeiro, 2004. Para uma aplicação da mesma hipótese ao poder Judiciário, ver: LEMOS, Renato Luís do C. Neto e. Poder Judiciário e poder militar (1964-1969). In: CASTRO, Celso et al. . (orgs.). Nova história militar brasileira. Rio de Janeiro: Editora FGV: Bom Texto, 2004. p. 409-438.

${ }^{12}$ Sobre a política de coerção do regime, ver:FIGUEIREDO, Marcus. A Política de Coação no Brasil Pós-64. In: KLEIN, Lúcia; FIGUEIREDO, Marcus. Legitimidade e coação no Brasil pós-64. Rio de Janeiro: Forense Universitária, 1978. p. 105-202 ; e VASCONCELOS, Cláudio Beserra de. Repressão a militares na ditadura pós-1964. Rio de Janeiro: Arquivo Nacional, 2018.
} 
instituições tradicionais da democracia apresentava-se como "uma" base potencial para a concretização de tal objetivo. A erradicação de tais normas e instituições inviabilizaria o projeto de legitimação e poderia afetar o exercício da hegemonia. A reiteração do compromisso do regime com a democracia era, como já afirmado, resultado de padrões de uma cultura política na qual se firmou a crença na importância de que ela deveria ser preservada.

A reiteração do compromisso da "Revolução" com a democracia não era, todavia, uma mera formalidade ou resultado de um cálculo de momento. Há dilemas, como bem observa Lamounier (1979, p. 93), em um processo complexo de legitimação, junto a uma sociedade igualmente complexa como a brasileira da década de 1960, que vão muito além das "aparências". É lógico que, nesse processo, havia um componente simbólico que contribuiu na busca do consentimento de determinadas parcelas da sociedade. Mas ele não era meramente simbólico. Era preciso que, ao mesmo tempo, ele assegurasse a unidade interna da corporação militar. Mas, cada ação do governo gerava discussões e divisões intestinas. Em paralelo, criava uma jurisprudência que "limitava" a ação militar nos momentos seguintes, já que, no nível simbólico os militares não podiam romper com o seu próprio discurso.

Em suma, como afirma Lamounier (1986, p. 314), no Brasil há um legado ideológico e institucional que apesar de possuir um caráter autoritário possui, também, componentes liberais que impossibilitam uma legitimação em termos duradouros de um sistema autoritário. Todavia, como é perceptível através da análise dos editoriais, essa preservação não era apresentada como adoção de um regime de "plenitude democrática”. Como solução, desencadeou-se um processo híbrido de dominação política, baseado em uma "democracia tutelada". Como dinâmica desse processo, o regime permitiu a "sobrevivência" de princípios e instituições típicos da democracia. Em uma relação de custo e benefício, acreditava que o provento da legitimidade que a preservação destes propiciaria seria maior do que os obstáculos que ele poderia impor ao governo.

No entanto, as bases de legitimidade criadas eram instáveis, provisórias e tendiam ao esgotamento. Sempre que surgia alguma crise, na tentativa de minorar as dissensões 
internas e de preservar a unidade institucional, o governo optava por tentar conciliar os interesses das diferentes facções militares. Essa dinâmica resultou na restrição das funções das instituições democráticas, e, em momentos cruciais, diante da exigência de observar as normas estabelecidas, levou o regime a optar por reformulá-las em seu próprio favor, ampliando a sua autonomia e área de interferência. Essa escolha subverteu o papel legitimador dos princípios democráticos. Por fim, a incoerência entre o discurso da preservação da democracia e a realidade opressiva gerou uma contínua crise de legitimidade no interior do Estado que acabou por corroer o seu alicerce.

As contradições entre a retórica democrática e a prática autoritária, somadas ao “espaço" que ela permitiu aos opositores, no entanto, geraram no interior da coalizão no poder inúmeros conflitos que marcaram todo o processo híbrido de dominação. Aos poucos, converteram-se em barreiras indesejadas. Em 1968, essa política híbrida de "democracia tutelada”, que mesclava um autoritarismo congênito a resquícios de legalidade democrática, apresentou claros sinais de desgaste. Sua manutenção tornou-se inviável. Em resposta, grupos militares passaram a cobrar com ainda mais veemência o endurecimento do regime. Tendo que optar pelo lado liberal ou pelo reforço do caráter autoritário do regime, escolheu-se a segunda opção. Contudo, por mais que, naquele momento, a opção tenha sido a de fechar os olhos à necessidade de legitimação junto à sociedade civil, ela não poderia ser ignorada para sempre. E não foi. Sucessivamente, novas bases de consenso foram buscadas, e, apesar da mudança naquele momento, o projeto original de "democracia tutelada" não foi definitivamente abandonado, sendo retomado, posteriormente, no governo do presidente Ernesto Geisel.

\section{Conclusão}

Nos últimos anos, boas obras foram publicadas sobre as relações entre imprensa e ditadura. Parte importante delas se ateve ao aspecto da censura à imprensa (JORGE, 1990; MARCONI, 1980; KUSHNIR, 2004). Ainda há muito a se estudar. Especialmente no que se refere aos laços político-ideológicos, às relações de classe que os une. Como percebe Gramsci, a imprensa atua como aparelho privado de hegemonia. Na república brasileira, esse caráter é marcante. De modo geral, ela atuou efetivamente no sentido de 
defender os interesses da classe empresarial da qual faz parte. Nos anos 1960, colaborou efetivamente da campanha contra o presidente João Goulart, defendeu o golpe e trabalhou de modo a consolidar a hegemonia do grupo que conquistou o Estado em 1964. A ideia do artigo era analisar, a partir de elementos linguísticos, retóricos, a forma como a imprensa dissimulou o seu apoio à ditadura, contribuindo para a hegemonia de uma classe, mas é preciso ir além.

Não havia a pretensão de negar que o que prevaleceu como forma de dominação social durante a ditadura foi a violência emanada a partir do controle do Executivo. A coerção é elemento central do processo de dominação de classe, mas não se pode ignorar a importância da criação do consenso para a hegemonia. Isso é significativo ainda nos dias de hoje. É preciso que nos questionemos sobre até que ponto, no contexto atual da realidade brasileira, a mídia não continua agindo dessa mesma forma, mas não só. É correto afirmar que a imprensa continua como parte importante desse processo, mas não podemos ficar limitados a ela. Precisamos questionar quais outros elementos têm sido usados para a difusão de ideias que geram convencimento e qual o grau de importância de cada um deles. É imperativo, também, não perdermos de vista o contexto mais geral, marcado pela emergência de expressões neofascistas em nossa sociedade. É fundamental identificar e analisar as disputas políticas atuais, o pé em que estão os conflitos de classe.

Vivemos um momento em que a disseminação de mentiras atingiu proporções gigantescas. O desprezo pelos fatos se tornou elemento central no processo de convencimento e, por consequência, na dominação de classe. Mentiras, desinformação, se prestam à disseminação de opiniões, ideias, ideologias, ajudam na criação do consenso. Nesse quadro, ainda que a grande imprensa não seja o instrumento por excelência de disseminação de mentiras, mesmo que ela tenha se tornado alvo de pesadas críticas, que sua credibilidade tenha sido questionada, até que ponto a sua postura omissa frente ao crescimento das forças de extrema direita e a preferência pela ocultação e/ou dissimulação de fatos não colaborou com a desinformação? Onde está a origem de tais argumentos? Como ela atuou para a desconstrução de tais mentiras, se é que atuou? Resumindo, duas questões centrais devem orientar os trabalhos atuais sobre 
a participação política da imprensa: qual a sua responsabilidade com relação à emergência de expressões neofascistas em nossa sociedade? Em tempos de pós-verdade, os interesses econômicos e financeiros se sobrepuseram à missão de questionar as mentiras propagadas pela extrema direita?

Cabe continuarmos a analisar a colaboração da imprensa no processo de construção do consentimento dos governados para com a hegemonia dos governantes. Para isso, apresenta-se como fundamental procurarmos trazer a lume os interesses que fazem com que a mídia, mesmo se apresentando como defensora do regime democrático, abrace, ou ao menos não se oponha, a ideias que atingem a essência da democracia.

É primordial, pois, estarmos atentos a um contexto amplo. Grande imprensa, blogs, influenciadores digitais têm interesses políticos, econômicos, ideológicos. Essas relações não podem ser perdidas de vista. Grupos formados em redes sociais também os têm. Nesse caso, tais filiações podem ser de mais árdua percepção, mas essa dificuldade não é justificativa para que não sejam buscadas. Os centros difusores de ideologias são múltiplos, os aparelhos privados de hegemonia, hoje, são mais diversos. Como se relacionam, como são articulados, como produzem e reproduzem ideias na atualidade, como participam do processo de construção da dominação de classe são temáticas ainda abordadas de modo incipiente. Carecem de uma atenção e investigações muito maiores.

\section{Referências}

ALVES, Maria Helena Moreira. Estado e oposição no Brasil, 1964-1984. 4. ed. Petrópolis: Vozes, 1984.

AZEVEDO, Luiz Vitor Tavares de. "A voz do dono": Tribuna de Imprensa: análise da ideologia de um discurso de oposição (1953-1955). Revista Brasileira de História, São Paulo, v. 7, n. 13, p. 63-76, set. 1986/fev. 1987. 
BADIOU, Alain. Ética: um ensaio sobre a consciência do mal. Rio de Janeiro: RelumeDumará, 1995.

BARDIN, Laurence. Análise de conteúdo. Lisboa: Edições 70, 1977.

BOURDIEU, Pierre. O poder simbólico. 3. ed. Rio de Janeiro: Bertrand Brasil, 2000.

BREGUÊS, Sebastião G. A imprensa brasileira após 64. Encontros com a Civilização Brasileira, Rio de Janeiro, n. 2, p. 145-163, 1978.

CARDOSO, Ciro Flamarion; VAINFAS, Ronaldo. História e análise de textos. In: CARDOSO, Ciro Flamarion; VAINFAS, Ronaldo. (orgs.). Domínios da história: ensaios de teoria e metodologia. Rio de Janeiro: Campus, 1997. p. 375-399.

CARDOSO, Ciro Flamarion; VAINFAS, Ronaldo. Semiótica, História e Classes Sociais. In: CARDOSO, Ciro Flamarion; VAINFAS, Ronaldo. Ensaios racionalistas: filosofia, ciências naturais e história. Rio de Janeiro: Campus, 1988. p. 61-92.

CHAUÍ, Marilena; FRANCO, Maria Sylvia Carvalho. Ideologia e mobilização popular. Rio de Janeiro: Paz e Terra, CEDEC, 1978.

COUTINHO, Carlos Nelson. Gramsci: um estudo sobre seu pensamento político. Rio de Janeiro: Campus, 1992.

DUARTE, Celina Rabello. Imprensa e Redemocratização no Brasil, Dados: Revista de Ciências Sociais, Rio de Janeiro, v. 26, n. 2, p. 181-195, 1983.

FICO, Carlos. Reinventando o otimismo: ditadura, propaganda e imaginário social no Brasil. Rio de Janeiro: FGV, 1997.

FIORIN, José Luiz. O regime de 1964: discurso e ideologia. São Paulo: Atual, 1988.

GRAMSCI, Antonio. Cadernos do cárcere. V. III. 3. ed. Rio de Janeiro: Civilização Brasileira, 2007.

KINZO, Maria D’Alva Gil. Oposição e autoritarismo: gênese e trajetória do MDB (19661979). São Paulo: Vértice: Editora Revista dos Tribunais, 1988.

LAMOUNIER, Bolivar. Authoritarian Brazil revisitado: o impacto das eleições na abertura política brasileira, 1974-1982, Dados: Revista de Ciências Sociais, Rio de Janeiro, v. 29, n. 3, p. 283-317, 1986.

LAMOUNIER, Bolivar. O discurso e o processo (da distensão às opções do regime brasileiro). In: RATTNER, Henrique (org.). Brasil 1990: caminhos alternativos do desenvolvimento. São Paulo: Editora Brasiliense, 1979. p. 88-120. 
MARIANI, Bethania. O PCB e a imprensa: os comunistas no imaginário dos jornais (19221989). Rio de Janeiro: Revan; Campinas: Editora da Universidade Estadual de Campinas, 1998.

MARX, Karl e ENGELS, Friedrich. A ideologia alemã. São Paulo: Martins Fontes, 1998.

MIGUEL, Luís Felipe. O jornalismo como sistema perito, Tempo Social: Revista de

Sociologia da USP, São Paulo, vo. 11, n. 1, p. 197-208, 1999.

ORLANDI, Eni Pulcinelli. Discurso e leitura. São Paulo: Cortez Editora; Campinas: Editora da Universidade Estadual de Campinas, 1996.

OSAKABE, Haquira. Argumentação e Discurso Político. 2. ed. São Paulo: Martins Fontes, 1999.

RIBEIRO, Ana Paula Goulart. Imprensa e história no Rio de Janeiro dos anos 50. 2000. Tese (Doutorado em Comunicação) - Universidade Federal do Rio de Janeiro, Rio de Janeiro, 2000.

SILVA, Carla Luciana. Imprensa e ditadura militar: padrões de qualidade e construção de memória. História \& Luta de Classes, ano 1, n. 1, p. 43-54, abr./2005.

SMITH, Anne-Marie. Um acordo forçado: o consentimento da imprensa à censura no Brasil. Rio de Janeiro: Editora da Fundação Getúlio Vargas, 2000.

SODRÉ, Nelson Werneck. História da imprensa no Brasil. 4. ed. São Paulo: Martins Fontes, 1999.

SOUZA, Ayda Connia de. O Estado autoritário: algumas questões sobre a legitimação, Revista UFRGS, Porto Alegre, ano 11/12, p. 335-346, 1983/1984.

STEPAN, Alfred C. Os Militares na política. Rio de Janeiro: Artenova, 1975.

ZOPPI-FONTANA, Mónica Graciela. Cidadãos modernos: discurso e representação política. Campinas: Editora da Universidade Estadual de Campinas, 1997.

\section{Fontes:}

A FORTE personalidade do novo líder. O Estado de São Paulo, São Paulo, ano 85, n. 27.295, p. 3, 16 de abr. de 1964.

A HORA de Castelo. O Globo, Rio de Janeiro, ano 42, n. 12.448, p. 1, 6 de dez. de 1966.

A MISSÃO do novo Presidente. O Estado de São Paulo, São Paulo, ano 87, n. 28.057, p. 3, 4 de out. de 1966. 
A REVOLUÇÃO Consolidada. O Globo, Rio de Janeiro, ano 39, n. 11.633, p. 1, 11 de abr. de 1964.

A VEZ do Congresso. O Globo, Rio de Janeiro, ano 39, n. 11.626, p. 1, 3 de abr. de 1964. ANÁLISE do pleito. O Globo, Rio de Janeiro, ano 44, n. 13.048, p. 1, 19 de nov. de 1968. AUTORIDADE. Jornal do Brasil, Rio de Janeiro, ano 74, n. 131, p. 6, 5 de jun. de 1964. DECISÃO urgente. Jornal do Brasil, Rio de Janeiro, ano 73, n. 79, p. 6, 4 de abr. de 1964. DIREITO de defesa. Jornal do Brasil, Rio de Janeiro, ano 75, n. 254, p. 6, 29 de out. de 1965.

ELEIÇÕES realizadas. O Estado de São Paulo, São Paulo, ano 86, n. 27.750, p. 3, 5 de out. de 1965.

EMPATE impossível. O Estado de São Paulo, São Paulo, ano 86, n. 27.768, p. 3, 26 de out. de 1965.

ESTATUTO Revolucionário. Jornal do Brasil, Rio de Janeiro, ano 76, n. 288, p. 6, 8 de dez. de 1966.

ETAPA Final. Jornal do Brasil, Rio de Janeiro, ano 75, n. 251, p. 6, 26 de out. de 1965.

FIM do Falso Liberalismo. O Globo, Rio de Janeiro, ano 42, n. 12.450, p. 1, 8 de dez. de 1966.

FORÇAS Armadas. Jornal do Brasil, Rio de Janeiro, ano 78, n. 129, p. 6, 7 de set. de 1968.

O ART. $3^{\circ}$ do A. Institucional e o espírito da Revolução. O Estado de São Paulo, São Paulo, ano 85, n. 27.293, p. 3, 14 de abr. de 1964.

O ATO Institucional. Jornal do Brasil, Rio de Janeiro, ano 74, n. 84, p. 6, 10 de abr. de 1964.

O BRASIL não voltará à corrupção e à subversão. O Globo, Rio de Janeiro, ano 41, n. 12.092, p. 1, 8 de out. de 1965.

O CAMINHO a seguir. O Estado de São Paulo, São Paulo, ano 86, n. 27.754, p. 3, 9 de out. de 1965.

O EDITO de Brasília. O Globo, Rio de Janeiro, ano 41, n. 12.109, p. 1, 28 de out. de 1965.

O ENDEREÇO da Carta. O Globo, Rio de Janeiro, ano 42, n. 12.451, p. 1, 9 de dez. de 1966. 
O INEVITÁVEL aconteceu. O Estado de São Paulo, São Paulo, ano 86, n. 27.770, p. 3, 28 de out. de 1965.

O NOVO Ato Institucional. O Estado de São Paulo, São Paulo, ano 86, n. 27.771, p. 3, 29 de out. de 1965.

O SALTO e o atleta. O Globo, Rio de Janeiro, ano 44, n. 13.086, p. 1, 4 de jan. de 1969.

O STF entre os militares e a Câmara. O Estado de São Paulo, São Paulo, ano 89, n. 28.687, p. 3, 16 de out. de 1968 .

O ÚNICO Imprevisível. O Globo, Rio de Janeiro, ano 42, n. 12.410, p. 1, 21 de out. de 1966.

PODERES e responsabilidades. Jornal do Brasil, Rio de Janeiro, ano 75, n. 253, p. 6, 28 de out. de 1965.

PROCESSO Revolucionário. Jornal do Brasil, Rio de Janeiro, ano 76, n. 287, p. 6, 7 de dez. de 1966.

RESPONSABILIDADE. Jornal do Brasil, Rio de Janeiro, ano 77, n. 6, p. 6, 7 de jan. de 1967.

RETROCESSO. Jornal do Brasil, Rio de Janeiro, ano 76, n. 241, p. 6, 13 de out. de 1966.

UM IMPASSE. Jornal do Brasil, Rio de Janeiro, ano 78, n. 175, p. 6, 31 de out. de 1968.

UM IMPERATIVO da consciência revolucionária. O Estado de São Paulo, São Paulo, ano 85, n. 27.361, p. 3, 3 de jul. de 1964.

VOTO de confiança. Jornal do Brasil, Rio de Janeiro, ano 74, n. 168, p. 6, 18 de jul. de 1964.

Recebido em 20/11/2018 Aprovado em 27/06/2019 
Revista Tempo e Argumento Volume 11 - Número 28 - Ano 2019 tempoeargumento@gmail.com 